\section{A Comparison of Factors that Affect Ranching Profits ${ }^{1}$}

\begin{abstract}
LORENZ F. BREDEMEIER
Range Conservationist, U.S. Deparlment of Agriculture, Soil Conservation Service, Fort Worth, Texas.

\section{Highlight}

To evaluate the impact of income and expense factors for beef cow-calf operations, 39 factors were identified. Using these, eight were evaluated independently for impact. A $\$ \mathbf{1 0 . 0 0}$ difference in net return per cow resulted from the following changes: $\mathbf{5 7 . 2}$ pounds selling weight per calf; 3.6 cents per pound of calf weight sold; 10.3 percent calf crop; $\$ 4.02$ per ton for hay; 12.2 months of pasture versus hay with hay at $\$ 14.00$ per ton or 4.1 months with hay at $\$ 18.00$ per ton; .2 animal unit months per acre in stocking rate; $\$ 25.30$ per acre grazing land value; and $\$ 9.04$ tax per animal unit. The input required to produce these changes and others related thereto must be assessed for each individual case before making resource use decisions for increasing income.
\end{abstract}

Range conservation and profits for the rancher are compatable objectives. Among the more frequent ways suggested for ranchers to increase profits are: heavier weaning weights, higher percentage calf crop, shorter feeding and supplementing periods, more productive forage, better quality forage, and timely selling for highest price.

Many studies using budgets have been made to help find the most profitable combinations of resources and enterprises. Hottel and Arnold (1965) presented budgets for alternative conditions in Arkansas. Oliver and Kline (1965) developed budgets for optimum enterprise combinations for beef cowcalf farms in southwestern Virginia. Olson (1959) used linear programming to select the best combinations of enterprises in eastern Ohio.

There is a continuing need to find new ways for landowners and operators to use economic data for increasing profits in harmony with good range conservation management. An approach for evaluating the impact of economic factors on the profits of a cow-calf operation is presented. The objective is

\footnotetext{
${ }^{1}$ Adapted from paper presented at the annual meeting of the American Society of Range Management held in Calgary, Alberta, Canada, February 11-13, 1969. Received April 5, 1969; accepted for publication December 8 , 1969.
}

to evaluate the relative impact of several factors on profits.

\section{Procedure}

Thirty-nine factors that influence returns to labor and management of a beef cow-calf operation were identified (Table 1). Values for each ranged from low to high based on data from ranchers' experience, publications in literature cited, and knowledgeable judgment. This range was divided into five equal units, "low," "medium low," "medium," "medium high," and "high." Any value may represent a rancher's three to five year average.

Table 1 is arranged into eight groups as used to figure: (1) herd organization, (2) gross income, (3) livestock investment and interest, (4) miscellaneous livestock expense, (5) pasture charge, (6) hay cost, (7) protein supplement cost, and (8) shelter and building charge.

A herd organization model was developed for a 150-cow herd using the "medium" values in Table 1 . Forage and feed needs were determined using an adaptation of the summary table (Rasmussen, 1958). The "medium" values of all factors were used to figure income and expense to the nearest dollar for a 150-cow herd (Table 2). The minus return to labor and management is disturbing, but it emphasizes realities. There are, however, plus values such as interest return to land and building investments, and land value appreciation. There may be other long term benefits as effect on water supply, value of land for recreation, and conservation of resources for future generations as pointed out by Ciriacy-Wantrup and Schultz (1957).

The minus return provokes speculation as to changes that could produce a profit. However, the focal point of this project is which factor has greatest influence on net returns. Eight factors were selected for this analysis. They are calf selling weights, calf selling price, percent calf crop, hay cost per ton, months grazing versus months haying, stocking rate (forage production), value of grazed land, and livestock property tax. All except livestock property tax are directly related to resource use. They are considered to have major influence on net income depending on the cost of achieving the changes. Net return was calculated at all five values with "medium" value used for all other factors. Thus the effect of the single factor on net return was projected.

\section{Results}

Net returns for a 150-cow herd from different calf sale weights and prices range from a minus $\$ 6,141$ to a plus of $\$ 684$ (Table 3). A plus return to labor and management resulted from 450 pound calves at 30 cents with all other income and expense factors at "medium" value. To determine the influence of a factor, differences in net income resulting from changes for a factor were determined using Table 3. Analysis of weight influence revealed that 25 pound changes in calf weight at 20 cents per pound resulted in $\$ 525$ difference in net income. The difference averaged $\$ 656.50$ at 25 cents and $\$ 787.50$ at 30 cents. When the influence of price was considered, 2.5 cents per pound produced an average difference of $\$ 918.75$ for 350 pound calves. It averaged $\$ 1,050$ for 400 pound calves and $\$ 1,181.25$ for 450 
Table 1. Management factors that influence net income of beef cow-calf ranches and values for each.

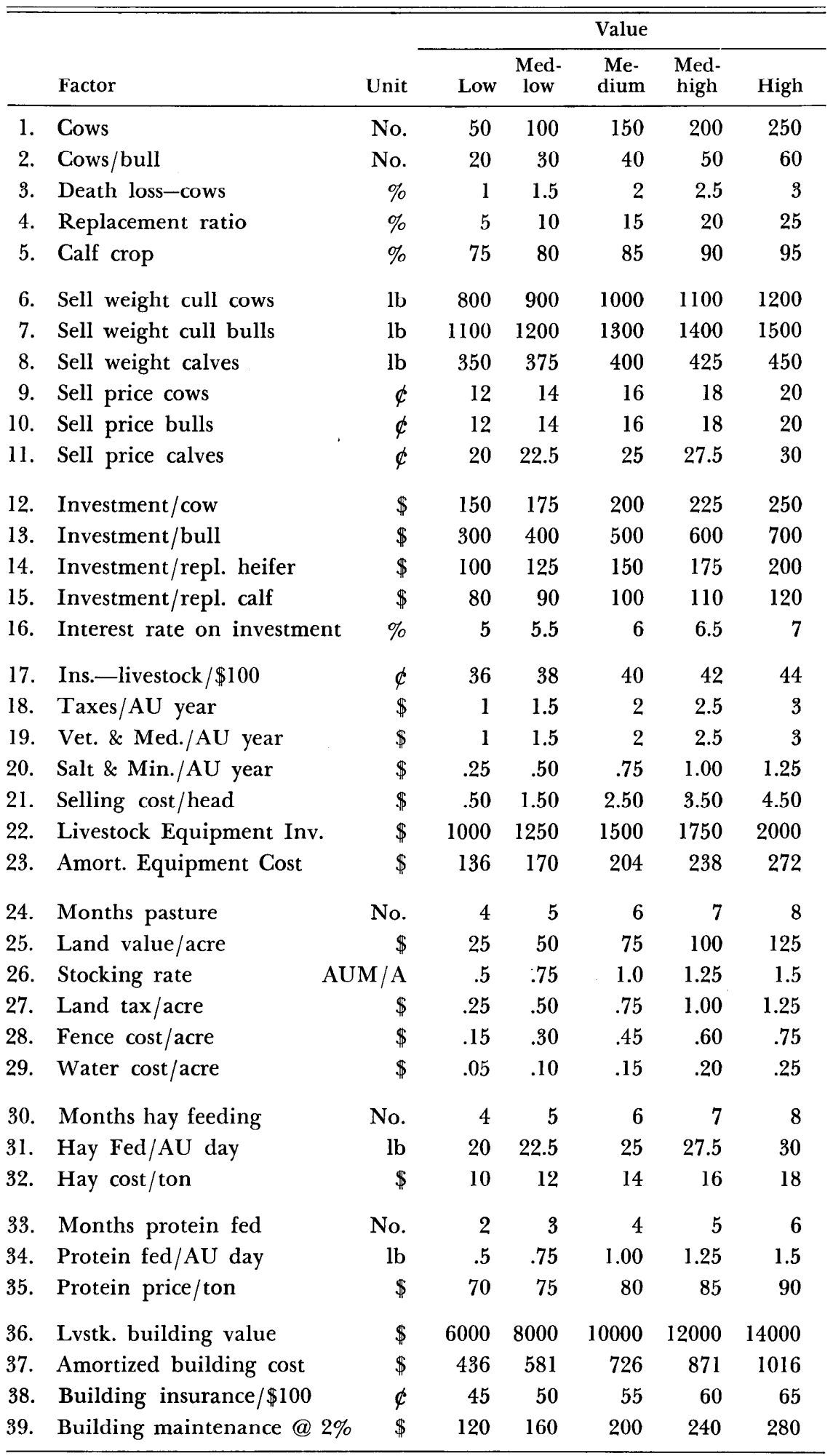

pounds. This illustrates the interrelated effect of two variables.

The same kinds of calculations were made and tables developed ence also were calculated for different personal property tax rates on livestock. This is a minor factor for influencing income as evidenced by the magnitude of change needed.

When the differences in net income were plotted the result was essentially a straight line for sale weight, sale price, cost of hay, percent calf crop, and land values. The month's grazing versus haying line was almost straight. It was governed by small differences in the monthly needs for animal unit months. Differences in net return due to changes in stocking rate produced a curved line. Differences were greater at lower stocking rates than at higher. This is because uniform stocking rate increment represents a higher percentage change at lower rates.

A common base is essential to compare the impact of different factors. Ten dollars per brood cow was chosen as a meaningful unit for comparison because this difference in income per brood cow in a herd seems significant. The differences resulting if the value of only one factor changed and all others remained at the "medium" value were used in calculating the comparison. The results are expressed as the amount of change in value of a factor needed to produce a $\$ 10$ difference in net return per cow. They are 57.2 pounds selling weight per calf; 3.6 cents per pound calf weight sold; 10.3 percent calf crop; $\$ 4.02$ per ton for hay; 12.2 months of pasture versus hay change with hay at $\$ 14.00$ per ton, or 4.1 month's change with hay at $\$ 18.00$ per ton; .2 AUM's per acre in stocking rate; $\$ 25.30$ per acre grazing land value; and $\$ 9.04$ tax per animal unit.

These figures will not be the same in all situations for the factors shown. The number of month's change necessary with hay at $\$ 14$ and $\$ 18$ per ton illustrates this.

Most ranchers in northern latitudes of the United States find that net returns are increased markedly by longer grazing seasons and shorter hay feeding periods. Results indicate that the basis for the 
Table 2. Net return calculations for a beef cow-calf ranch with 150 cows.

Herd information

Cows kept to calve

Replacement heifers@15\%

Replacement calves@15\%

Bulls@1 to 40 cows

Total calves @ 85\%

Less replacement heifer calves

150

22.5

22.5

3.75

127.5

22.5

Income

Calves for sale

Beef for sale (No. calves $\times 400$ lbs.)

Incomc from calves@.25

Cows for sale after $2 \%$ death loss

Beef for sale (No. cows $\times 1000$ lbs.)

Income from cows@.16

Bulls for sale $1 / 3$ per year

Beef for sale (No. bulls $\times 1300$ lbs.)

Income from bulls@.16

Total income

Expense

Investment

Cows. Average No. for year $\times \$ 200$

Bulls. Average No. for year $\times \$ 500$

Replacement heifers. Avg. No. for year $\times \$ 150$

Heifer calves. Avg. No. for year $\times \$ 100$

Total investment

Interest on livestock investment @6\%

Miscellaneous livestock costs

Ins. livestock investment $\times \$ .40 / 100$

Taxes. Avg. No. AU for year $\times \$ 2$

Vet \& medical. Avg. No. for year $\times \$ 2$

Salt \& mineral. Avg. No. for year $\times \$ .75$

Selling cost. No. head sold $\times \$ 2.50$

Bull replacement. No. $\times \$ 500$

Equipment cost. Amort. from table

Total miscellaneous livestock costs

Grazing cost

Land charge. AUM's neèded $\times \$ 4.50$

Land tax. Acres needed $\times \$ .75$

Fence cost amort. Acres needed $\times \$ . .45$

Water cost amort. Acres needed $\times \$ .15$

Total grazing cost

Hay cost $.375 \mathrm{~T} \times 994.5 \mathrm{AUM} \times \$ 14 / \mathrm{T}$

Protein supplement cost 4 months $\times 165.75$

Avg. AU's $\times \$ 1.20$

Building costs

Building cost Amort. from table

Building Ins. value $\times \$ .55 / 100$

Building maintenance from table

$\$ 726$

55

200
$\$ 27,800$

1,875

3,375

750

$\$ 33,800$

$\$ 135$

332

332

124

314

625

204

$\$ 4,445$

741

445

148
1.25

9.5

Total building costs

$\$ 2,028$

$\$ 260$

$\$ 13,880$

$\$ 3,120$

$\$ 10,500$

\$

$\$ 13,880$ 
Table 3. Net returns and differences (dollars) from different calf sale weights (pound) and selling prices (dollars) based on a 150-cow herd.

\begin{tabular}{lllllll}
\hline \hline \multirow{2}{*}{$\begin{array}{c}\text { Selling } \\
\text { price }\end{array}$} & \multicolumn{5}{c}{ Calf sale weights } & $\begin{array}{c}\text { Average } \\
\text { dollars/ } \\
25 \text { lbs. }\end{array}$ \\
\cline { 2 - 7 } .20 & -6141 & -5616 & -5091 & -4566 & -4041 & $525^{\mathrm{a}}$ \\
.225 & -5222 & -4631 & -4041 & -3450 & -2860 & $590.5^{\mathrm{a}}$ \\
.25 & -4304 & -3647 & -2991 & -2335 & -1679 & $656.5^{\mathrm{a}}$ \\
.275 & -3385 & -2663 & -1941 & -1219 & -497 & $722^{\mathrm{a}}$ \\
.30 & -2466 & -1679 & -891 & -104 & +684 & $787.5^{\mathrm{a}}$ \\
$\begin{array}{l}\text { Average dollars at } \\
.025 \text { per pound }\end{array}$ & $918.75^{\mathrm{b}}$ & $984.25^{\mathrm{b}}$ & $1050^{\mathrm{b}}$ & $1115.5^{\mathrm{b}}$ & $1181.25^{\mathrm{b}}$ \\
\hline
\end{tabular}

a Difference in net income due to 25 pounds change in calf sale weight.

b Difference in net income due to $2.5 \not$ per pound change in calf sale price.

\section{Literature Cited}

Beaty, E. R., J. D. Powell, J. C. FortSON, ANd F. B. SAunders. 1963. Production aspects of a beef cow-calf operation on grass pastures. J. Range Manage. 16:250-253.

Ciriacy-Wantrup, S. V., and A. M. Schultz. 1957. Problems involving conservation in range economics research. J. Range Manage. 10:12-16.

Doane's Agriculture Report. 1968. Do you know what it costs to keep a cow? Sep. 8, pp. 20-25.

Gerlow, A. R., and J. R. Campbell. 1965. Enterprise costs and returns for beef cattle, Southern Louisiana rice area. La. Agr. Exp. Sta. DAE, Res. Rep. No. 337.

High, T. W., JR., E. J. Chapman, B. L.
Whittenberg, and J. W. High, JR. 1965. Fescuc pasturcs, under different management systems, and orchardgrass-clover for yearlong slaughter steer production. Tenn. Agr. Exp. Sta. Bul. 385.

Hottell, J. B., ANd A. F. ARnold. 1965. Crop pasture, timber and livestock enterprises for the Boston Mountain and Ozark Highland arcas of Arkansas. Ark. Exp. Sta. Rpt. Series 135, pp. 13-66.

Kearl, W. A. 1961. Cattle ranching in the Northern Plains area of Wyoming. Wyo. Agr. Exp. Sta. Mimeo Cir. No. 155.

Launchbaugh, J. L. 1957. The effect of stocking rate on cattle gains and on native shortgrass vegetation in west-central Kansas. Ft. Hays Branch Kan. Agr. Exp. Sta. Bul. 394.

LeitneAd, H. L. 1960 . Grass management pays big dividends. J. Range Manage. 13:206-210.

Mueller, R. G., AND G. A. Harris. 1967. Economics of selected alternative calving dates. J. Range Manage. 20:67-69.

Oliver, J. D., AND R. G. Kuine. 1965. Optimum enterprise combinations for beef cow and calf farms in southwest Virginia. Vir. Agr. Exp. Sta. Tech. Bul. 180.

Olson, R. O. 1959. Some opportunities for improving farm income in southeastern Ohio. Ohio Agr. Exp. Sta. Res. Bul. 832.

Rasmussen, L. H. 1958. Balancing livestock numbers, feed and forage on ranching units. J. Range Manage. 11:194-197.

Rieck, R. E., G. C. Pulver, and W. Henquinet. 1966. Beef cow costs and returns in northern Wisconsin. Wis. Agr. Exp. Sta. Res. Rep. 22.

Wells, A. R., ANd S. A. Eugene. 1966. Costs and returns of beef cow herds. Minn. Uni. Farm Business Notes No. 489.

Western, C., and A. W. Epp. 1965. The Nebraska sandhills ranch business, 1965 summary. Nebr. Uni., Agr. Col. Agr. Econ. Dep. Memo.

Willinte, F. M., and A. R. Grable. 1966. Greater profit from livestock in the intermountain west with efficient ranch management. J. Range Manage. 19:112-118.

\section{THESIS: UNIVERSITY OF WYOMING}

\section{Diet Preference and Utilization Patterns of Elk in the Northern Big Horn Mountains, Wyoming, by George E. Probasco. M.S. Range Management, 1968.}

Data were collected during the summer of 1967, on dietary preferences and grazing patterns of elk in the northern Big Horn Mountains of Wyoming. Forest openings, where only elk grazing occurred, were studied to determine preferred plant species for both the spring and summer seasons.

One forest opening of approximately 300 acres was stratified to determine if there was a correlation between elk grazing patterns and distance from forest margin. Elk grazing patterns were found to be not correlated with distance from forest margin. However, there was a definite correla- tion between elk grazing patterns and percent total basal cover of herbaceous vegetation.

Data on diet preferences indicated that elk utilized grasses during the spring period but shifted their preference to forbs during the summer season. Preferred species for the spring period were Bromus marginatus, Bromus spp., Festuca idahoensis, and Poa spp. Preferred species for the summer period were Agoseris glauca, Balsamorrhiza incana, Potentilla diversifolia, and Astragalus miser. 